\title{
Interbacterial transfer of carbapenem resistance and large antibiotic resistance islands by natural transformation in pathogenic Acinetobacter
}

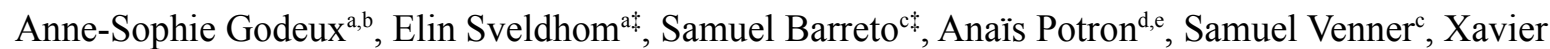 \\ Charpentier, ${ }^{\mathrm{a}, \#, *}$ and Maria-Halima Laaberki ${ }^{\mathrm{a}, \mathrm{b}, \#, *}$
}

\begin{abstract}
a. CIRI, Centre International de Recherche en Infectiologie, Inserm, U1111, Université Claude Bernard Lyon 1, CNRS, UMR5308, École Normale Supérieure de Lyon, Univ Lyon, 69100, Villeurbanne, France. Team Horigene, https://horigene.fr b. Université de Lyon, VetAgro Sup, 69280 Marcy l'Etoile, France.

c. UMR CNRS 5558 - LBBE "Laboratoire de Biométrie et Biologie Évolutive", Université Claude Bernard Lyon 1, Villeurbanne, France.

d. French National Reference Center for Antibiotic Resistance, University Hospital of Besançon, Besançon, France

e. UMR6249, CNRS Chrono-Environnement, Franche-Comté University, Besançon, France.

$\$$ Contributed equally

* Contributed equally

* Correspondence to :

maria-halima.laaberki@vetagro-sup.fr $\mid @$ Science_MHL

xavier.charpentier@univ-lyon1.fr |@1abXC
\end{abstract}

\section{Abstract}

Acinetobacter baumannii infection poses a major health threat with recurrent treatment failure due to antibiotic resistance, notably to carbapenems. While genomic analyses of clinical strains indicate that homologous recombination plays a major role in the acquisition of antibiotic resistance genes, the underlying mechanisms of horizontal gene transfer often remain speculative. Our understanding of the acquisition of antibiotic resistance is hampered by the lack of experimental systems able to reproduce genomic observations. We here report the detection of recombination events occurring spontaneously in mixed bacterial populations and which can result in the acquisition of resistance to carbapenems. We show that natural transformation is the main driver of intra-, but also inter-strain recombination events between $A$. baumannii clinical isolates and pathogenic species of Acinetobacter. We observed that interbacterial natural transformation in mixed populations is more efficient at promoting the acquisition of large resistance islands (AbaR4, AbaR1) than when the same bacteria are supplied with large amounts of purified genomic DNA. Importantly, analysis of the genomes of the recombinant progeny revealed large recombination tracts (from 13 to $123 \mathrm{~kb}$ ) similar to those observed in the genome of clinical isolates. Moreover, we highlight that transforming DNA availability is a key determinant of the rate of recombinants and results from both spontaneous release and interbacterial predatory behavior. In the light of our results, natural transformation should be considered as a leading mechanism of genome recombination and horizontal gene transfer of antibiotic resistance genes in Acinetobacter baumannii.

\section{Importance}

Acinetobacter baumannii is a multidrug resistant pathogen responsible for difficult-to-treat hospital-acquired infections. Understanding the mechanisms leading to the emergence of the multi-drug resistance in this pathogen is today crucial. Horizontal gene transfer is assumed to largely contribute to this multidrug resistance. However, in A. baumannii, the mechanisms leading to genome recombination and the horizontal transfer of resistance genes are poorly understood. We bring experimental evidence that natural transformation, a horizontal gene transfer mechanism recently highlighted in A. baumannii, allows the highly efficient interbacterial transfer of genetic elements carrying resistance to last line antibiotic carbapenems. Importantly, we demonstrated that natural transformation, occurring in mixed populations of Acinetobacter, enables the transfer of large resistance island mobilizing multiple resistance genes. 
bioRxiv preprint doi: https://doi.org/10.1101/2021.08.05.455225; this version posted August 30, 2021. The copyright holder for this preprint (which was not certified by peer review) is the author/funder, who has granted bioRxiv a license to display the preprint in perpetuity. It is made available under aCC-BY-NC-ND 4.0 International license.

\section{Introduction}

Acinetobacter baumannii is a gram-negative bacterium responsible for a wide range of infections in both humans and animals $(1,2)$. This multidrug-resistant (MDR) agent poses a health threat, particularly in intensive care units where it can lead to bacteremia and ventilator-associated pneumonia. Consequently, secondary infections with multidrug-resistant $A$. baumannii have been reported during the COVID-19 pandemic $(3,4)$. A. baumannii infections are steadily resistant to multiple antibiotics including to carbapenems. For Europe only, a combined resistance to fluoroquinolones, aminoglycosides and carbapenems is observed for nearly $30 \%$ of invasive Acinetobacter sp. isolates (5). In A. baumannii, carbapenem resistance is mainly associated with the expression of OXA23 carbapenemase encoded by the bla ${ }_{\text {OXA-23 }}$ gene (6). The composite transposon Tn2006, formed by two ISAba1 insertion sequences framing the bla OXA-23 gene, is the main genetic context for the bla OXA-23 gene and can be found in different locations, including plasmids, but it is most often found inserted in the large resistance island AbaR4 $(6,7)$. Such large and diverse $A$. baumannii resistance islands (Ab-RI) are potential contributors to the multi-drug resistance phenotype observed in A. baumannii. The first description of an Ab-RI was reported in 2006 in the epidemic strain AYE with the AbaR1 island consisting in an $86 \mathrm{~kb}$-long genomic structure (8). Since then, analysis of more than 3,000 A. baumannii genomes revealed that Ab-Rls are present in nearly $65 \%$ of them (9). These genomic island present a great diversity in gene content with often multiple putative antibiotic-resistance genes $(10,11)$. Ab-RI were presumed to be initially acquired through plasmid conjugation followed by chromosomal insertion, and evolve through multiple insertions and rearrangements of insertion sequences $(12,13)$. However, genome analyses also support their horizontal transfer between distantly related isolates, as exemplified by the acquisition of the $21 \mathrm{~kb}$-long ABGRI3 resistance island (14) or the $35 \mathrm{~kb}$-long AbGRI5 (15). Both acquisition involved large recombination events (up to $34 \mathrm{~kb}$-long) at the sequence flanking the island. Indeed, high rates of genome recombination is a hallmark of $A$. baumannii genomes $(16,17)$. Recombination events may have led to the acquisition by MDR strains of parC or gyrA alleles conferring resistance to fluoroquinolones and of ISAba1 upstream of the ampC gene leading to resistance to $3^{\text {rd }}$ generation cephalosporins $(14,17,18)$. Genome analysis of isolates from a longitudinal study also offered a glimpse of the gene transfer and recombination going on in the hospital setting, with the acquisition of the bla OXA-72 variant of the bla OXA24/40-type carbapenemase gene and recombination affecting the bla OXA-51 locus (19).

Despite their importance in the evolution of $A$. baumannii into an MDR pathogen, the mechanisms leading to genome recombination and recombination-dependent acquisition of resistance genes and Ab-RI remain elusive. Indeed, few studies have experimentally investigated the horizontal transfer of chromosomal antibiotic resistance genes in A. baumannii. The chromosomal transfer of an $11 \mathrm{~kb}-$ long Tn215 harboring the $b / a_{\mathrm{NDM}-1}$ during mating of the isolate R2090 to the reference strain CIP 70.10 was experimentally observed and involved the acquisition of a $65 \mathrm{~kb}$ region through homologous recombination (20). While transduction by prophages was suggested, the mechanism of transfer was not elucidated. Phage particles, present in prepared fractions from culture supernatant of the clinical isolate NU-60 were found to mediate chromosomal transfer to the reference strain ATCC17978 (21). If generalized transduction by strain-specific prophages is a potential mechanism of resistance gene transmission, natural transformation is another potential and highly conserved route. Natural transformation allows bacteria to actively import exogenous DNA and, provided a sufficient sequence identity, it integrates the recipient cell's genome by homologous recombination (22). Most A. baumannii isolates and also closely related Acinetobacter nosocomialis were found capable of natural transformation when presented with purified DNA (23-27). Yet, we currently have a limited understanding of the role of natural transformation in genome dynamics and the spread of antibiotic resistance in $A$. baumannii populations.

In the current study, we explored the inter-species and inter-genus transfer of antibiotic resistance, notably to carbapenems, which is spontaneously occurring in mixed populations of pathogenic Acinetobacter sp.. We provide evidence that natural transformation is the main transfer route and fosters recombination events and the acquisition of multiple resistance genes carried by large genomic island. Experimentally replicating the large recombination events observed in $A$. baumannii chromosomes, our results suggest a major role played by natural transformation in the dynamics of $A$. baumannii genomes. 
bioRxiv preprint doi: https://doi.org/10.1101/2021.08.05.455225; this version posted August 30, 2021. The copyright holder for this preprint (which was not certified by peer review) is the author/funder, who has granted bioRxiv a license to display the preprint in perpetuity. It is made available under aCC-BY-NC-ND 4.0 International license.

\section{Results}

\section{Intra and interspecies recombinants are produced in mixed populations of pathogenic Acinetobacter}

To test the possible transfer of antibiotic resistance in mixed populations, we first assessed if recombinants could arise in cultures of isolates harboring distinct resistance determinants. Three imipenem-resistant $\left(\mathrm{Imi}^{\mathrm{R}}\right)$ A. baumannii clinical isolates (AB5075, 40288, CNRAB1) and seven imipenem sensitive isolates either from the baumannii (29D2, A118, AYE, 27304, 29R1, 27024) or nosocomialis (M2) species were selected. Rifampicin-resistant $\left(\mathrm{Rif}^{\mathrm{R}}\right)$ mutants of the $\mathrm{Imi}^{\mathrm{S}}$ isolates were obtained. Each of these imipenem sensitive and $\mathrm{Rif}^{R}$ isolates was grown for 24 hours in mixed culture with each $I \mathrm{mi}^{R}$ isolate. The frequency of $\mathrm{Rif}^{R} / / \mathrm{mi}^{R}$ recombinants in the mixed cultures was then determined. $\mathrm{Rif}^{R} / \mathrm{Imi}^{\mathrm{R}}$ recombinants were detected in 19 of the 21 tested combinations with highly variable frequencies ranging from $2.10 \times 10^{-9}$ to $4.82 \times 10^{-4}$ (Fig. 1). Importantly, imipenem-sensitive isolate did not become $\operatorname{Imi}^{\mathrm{R}}$ in the absence of an $\mathrm{Imi}^{\mathrm{R}}$ isolate. And similarly, in the absence of $\mathrm{Rif}^{R}$ isolates, $\mathrm{Imi}^{R}$ isolates spontaneously develop resistance to rifampicin at frequencies below that of the detection limit of this assay $\left(10^{-9}\right)$. This strongly suggests that $\mathrm{Rif}^{\mathrm{R}} / \mathrm{Imi}^{\mathrm{R}}$ recombinants result from horizontal gene transfer between the mixed isolates. All tested isolates were capable of natural transformation under the tested growth conditions when presented with purified genomic DNA (gDNA) extracted from their own rifampicin resistant $\left(\mathrm{Rif}^{\mathrm{R}}\right)$ derivative (Fig. 1). Most isolates showed high transformability (transformation frequencies> $1 \times 10^{-3}$ ) while two isolates (CNRAB1 and 27024) presented lower transformation frequencies $\left(1 \times 10^{-6}\right)$. Pairing these two isolates generated only few recombinants, while pairing them with a more transformable isolate generated up to 10,000 times more recombinants, suggesting that at least one of the two isolates needs to be transformable to obtain recombinants. Yet, some combinations of highly transformable isolates were poorly productive of recombinants (40288 x AYE), suggesting that factors other than the intrinsic transformability of the isolates play a role in the production of a recombinant progeny.

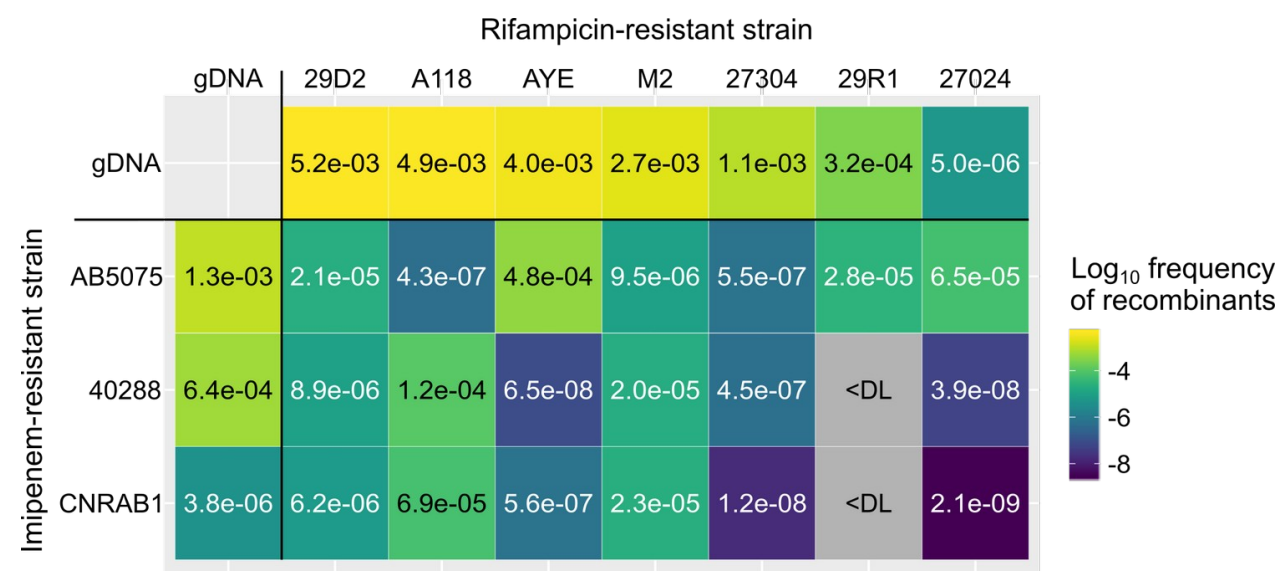

Figure 1. Recombinants are produced in mixed cultures of A. baumannii and A. nosocomialis.

Bacterial suspensions of rifampicin-resistant $\left(\mathrm{Rif}^{\mathrm{R}}\right)$ isolates of carbapenem-sensitive strains (29D2, A118, AYE, M2, 27304, 29R1 and 27024) were mixed with the carbapenem-resistant $\left(\operatorname{Imi}^{\mathrm{R}}\right)$ clinical isolates AB5075, 40288 or CNRAB1 using cultures adjusted to an $\mathrm{OD}_{600 \mathrm{~nm}}$ of 0.01 . The mixture $(2.5 \mu \mathrm{L})$ was deposited on the surface of tryptone-NaCl medium and incubated overnight at $37^{\circ} \mathrm{C}$. Rif $^{\mathrm{R}}$ and $\mathrm{Imi}^{\mathrm{R}}$ recombinants were determined after $24 \mathrm{~h}$ of mixed culture. Recombinant frequencies represent the ratio of Rif ${ }^{\mathrm{R}}$ and $\mathrm{Imi}^{\mathrm{R}}$ colony-forming units (CFUs) over the total CFU counts. Frequency of recombinants are presented as a heat map with indicated average frequencies from two or three biological replicates with three technical replicates each. $<$ DL, below detection limit $\left(\sim 10^{-9}\right)$. Top row and outermost left column show the transformation frequency displayed under the same condition by the unmixed isolates, tested by incubating the original isolates with genomic DNA (gDNA) extracted from their rifampicin (Rif ${ }^{\mathrm{R}}$ derivatives. The transformation frequencies (ratio of Rif ${ }^{\mathrm{R}}$ CFUs by total CFUs counts) are represented by a color gradient from blue to yellow. Data shown are the mean of natural transformation assays done in two or three biological replicates with three technical replicates each.

\section{Pathogenic Acinetobacter rapidly acquire carbapenem resistance by natural transformation in mixed culture}

The conditions under which we observed the rise of recombinants are permissive to natural transformation, yet we could not rule out other mechanism of horizontal gene transfer. Natural transformation has been previously reported to occur during exponential growth in $A$. baumannii $(27,28)$. Therefore, we sought to determine whether the kinetics of increasing recombinant numbers under mixed culture are consistent with a role of natural transformation. Focusing on the M2 x 40288 combination of two pathogenic Acinetobacter 
bioRxiv preprint doi: https://doi.org/10.1101/2021.08.05.455225; this version posted August 30, 2021. The copyright holder for this preprint (which was not certified by peer review) is the author/funder, who has granted bioRxiv a license to display the preprint in perpetuity. It is made available under aCC-BY-NC-ND 4.0 International license.

strains, we could detect recombinants as early as 3 hours after mixing the two isolates (Fig. 2A). The frequency of recombinants reached a plateau at 6 hours. The kinetic of emergence of recombinant is strikingly similar when we provided the M2 isolate with genomic DNA of 40288, further indicating that recombinants emerge by natural transformation (Fig. 2A). Indeed, in a 4 hours-long mixed culture experiment, addition of DNAse I reduced the size of the recombinant population by two orders of magnitude (Fig. 2B). To further validate the role of natural transformation, we tested the emergence of recombinants by $\triangle c o m E C$ ::aacC4 derivatives, which are impaired for the import of DNA. The association of the M2 strain with the $40288 \triangle c o m E C$ mutant did not alter the rate of recombinants (Fig. 2C). However, inactivating comEC in the M2 strain completely abolished the production of recombinants, indicating that the recombinants are formed by M2 bacteria which have acquired the carbapenem resistance by natural transformation. Similarly, the results demonstrate that the AYE and 27024 strains use natural transformation to acquire the carbapenem resistance of AB5075 (Fig. 2C). Interestingly, carbapenem-resistant transformants of 27024 are produced at rates higher than the transformation rate of 27024 when tested with its own gDNA conferring resistance to rifampicin (Fig. 1). This suggests that acquisition of carbapenem resistance is more effective than the acquisition of the mutation in the $r p o B$ gene conferring resistance to rifampicin. The mutations in this housekeeping gene are probably highly costly in terms of fitness $(29,30)$ which may explain the absence of recombinants resulting from the acquisition of the rifampicin resistance by transformable carbapenemresistant isolates. In conclusion, in mixed populations of Acinetobacter, carbapenem resistance can rapidly and efficiently spread to susceptible isolates by natural transformation.

A

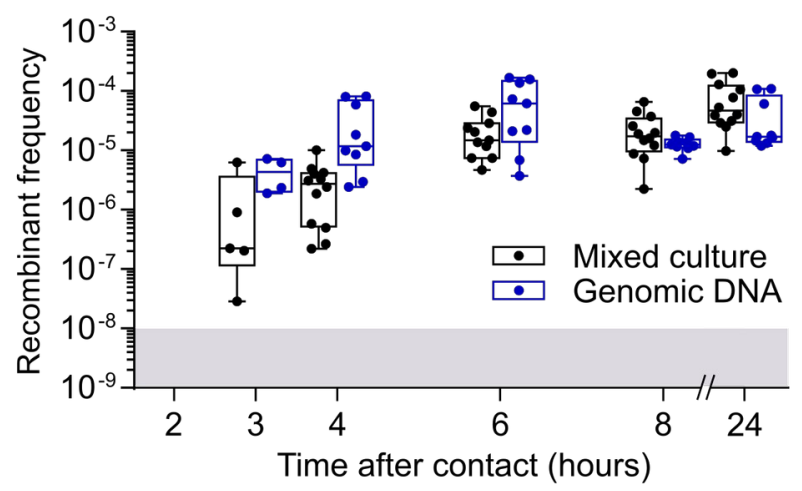

C

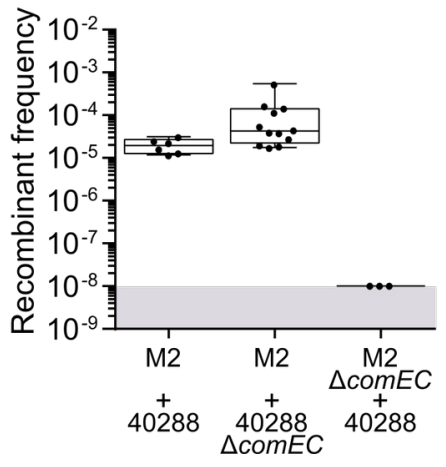

B
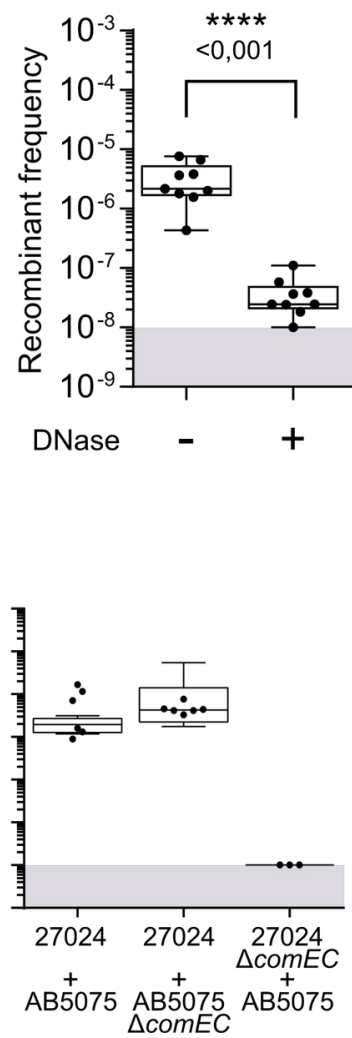

Figure 2. Acquisition of carbapenem resistance by natural transformation in a mixed culture.

A. Kinetic of emergence of carbapenem and rifamipicin-resistant recombinants in a mixed culture of $\mathrm{M} 2 \mathrm{Rif}^{\mathrm{R}}$ and 40288 (Imi ${ }^{\mathrm{R}}$ ) Bacterial suspensions of M2 Rif $^{\mathrm{R}}$ at an $\mathrm{OD}_{600 \mathrm{~nm}}$ of 0.01 were mixed with either an equal volume of a suspension of 40288 at an $\mathrm{OD}_{600 \mathrm{~nm}}$ of 0.01 or with gDNA extracted from 40288 (at $200 \mathrm{ng} / \mu \mathrm{L}$ ). The mixture $(2.5 \mu \mathrm{L})$ was deposited on the surface of tryptone$\mathrm{NaCl}$ medium and incubated overnight at $37^{\circ} \mathrm{C}$. Recombinant frequencies represent the ratio of Rif ${ }^{\mathrm{R}}$ and Imi ${ }^{\mathrm{R}}$ colony-forming units (CFUs) over the total. The limit of detection $\left(10^{-8}\right)$ is indicated by the grey area. B. Sensitivity of recombinants frequencies to DNAse I treatment under the same conditions as in A, with a mixed culture of 6 hours. C. Recombinants emerge by the ComECdependent acquisition of carbapenem resistance by susceptible isolates. Rifampicin-resistant (Rif ${ }^{\mathrm{R}}$ ) isolates of M2, AYE, 27024 or their comEC mutants were mixed with the carbapenem-resistant ( $\mathrm{Imi}^{\mathrm{R}}$ ) clinical isolates 40288 , AB5075 or their comEC mutants. $\mathrm{Rif}^{\mathrm{R}}$ and $\mathrm{Imi}^{\mathrm{R}}$ recombinants were determined after $24 \mathrm{~h}$ of mixed culture. The boxplots represent the distributions of Rif ${ }^{\mathrm{R}}$ and Imi ${ }^{\mathrm{R}}$ recombinants divided by the total CFU count (recombinant frequencies). A horizontal line representing the median. The limit of detection $\left(10^{-8}\right)$ is indicated by the grey area. In panel B, statistical analysis was conducted using the non-parametric MannWhitney-Wilcoxon test (two tailed). p-values are indicated. 
bioRxiv preprint doi: https://doi.org/10.1101/2021.08.05.455225; this version posted August 30, 2021. The copyright holder for this preprint (which was not certified by peer review) is the author/funder, who has granted bioRxiv a license to display the preprint in perpetuity. It is made available under aCC-BY-NC-ND 4.0 International license.

\section{Chromosomal DNA transfer is stimulated by T6SS-killing activity, but primarily relies of contact- independent spontaneous release of DNA}

The essential role of natural transformation in the acquisition of carbapenem resistance suggests that chromosomal DNA of the carbapenem-resistant isolate is released during the mixed culture. In Vibrio cholerae, the Type VI secretion system (T6SS) mediates the killing of non-kin cells, promoting the DNA release from prey cells which is then imported by natural transformation by the predating bacteria (31). Acinetobacter baylyi also produces a T6SS to kill preys, allowing the uptake of their DNA (32). In order to determine the contribution of T6SS-dependent killing on the chromosomal DNA transfer in the Acinetobacter mixed culture, we examined the combination of strains 40288 and M2, the latter being known for producing an active T6SS in LB medium (33). Under these conditions, we confirmed that M2 efficiently kills the 40288 strain, with a reduction of the population of 40288 by four orders of magnitude (Fig. S1A). A $\Delta h c p$ mutant of the M2 strain could not kill 40288, demonstrating that killing is indeed T6SS-dependent (Fig. S1A). However, in the condition in which we observed transformation-dependent chromosomal transfer, the T6SS of M2 is presumably poorly active with titers of viable 40288 cells comparable when mixed for 4 hours with either M2 or its $\Delta h c p$ derivative (Fig. S1B). Yet, inactivating the T6SS of M2 slightly lowered the rate of observed recombinants at 4 hours, and reduced it by one order of magnitude at 24 hours (Fig. 3A). This indicates that the residual activity of the T6SS contributes to DNA release and the acquisition of chromosomal DNA by the M2 strain. Yet, even in the absence of a functional T6SS, the rates of recombinants remained high, at a frequency of $10^{-5}$. We thus hypothesized that DNA is also released independently of the contact-dependent killing by the T6SS. To test this hypothesis, we collected culture supernatant of 40288 at 4 hours in the absence of M2. The M2 strain presented with this spent medium could acquire the carbapenem resistance almost as efficiently as during the mixed culture with 40288 or when presented with purified genomic DNA of 40288 (Fig. 3B). No carbapenem-resistant recombinants were observed when the spent medium was treated with DNase I or if the M2 strain is inactivated for DNA uptake $(\triangle c o m E C)$. This demonstrated that contactindependent release of DNA is sufficient to promote acquisition of chromosomal DNA by non-kin cells.
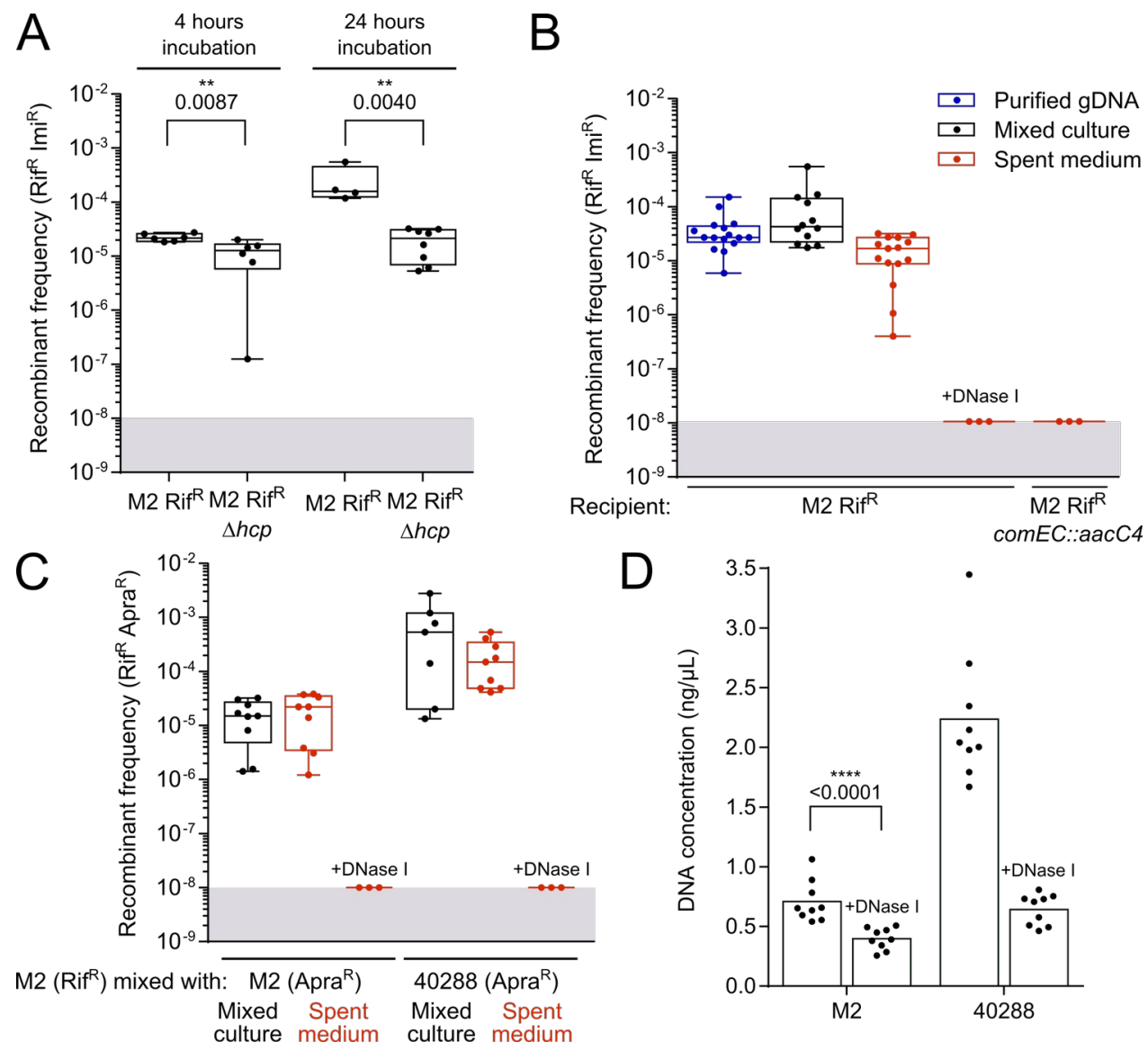

Figure 3. Contribution of contact-dependent T6SS-killing activity and contact-independent DNA release in the acquisition of the carbapenem resistance in mixed cultures.

A. Contribution of the T6SS in the frequency of recombinants generated in a mixed culture of 40288 and M2 Rif ${ }^{\mathrm{R}} .40288$ was mixed with the M2 iff $^{\mathrm{R}}$ strain or the M2 Rif ${ }^{\mathrm{R}} \Delta h c p$ mutant defective for T6SS activity. Imipenem-resistant transformants of the M2 strain were determined after 4 hours or 24 hours of mixed culture. Transformation frequencies represents the ratio of M2 Rif ${ }^{\mathrm{R}}$ Imi ${ }^{\mathrm{R}}$ 
bioRxiv preprint doi: https://doi.org/10.1101/2021.08.05.455225; this version posted August 30, 2021. The copyright holder for this preprint (which was not certified by peer review) is the author/funder, who has granted bioRxiv a license to display the preprint in perpetuity. It is made available under aCC-BY-NC-ND 4.0 International license.

CFUs over the total count of M2 Rif $^{\mathrm{R}}$ CFUs. B. Contribution of contact-independent DNA release by 40288 in the acquisition of the imipenem resistance by M2 in mixed culture. Bacterial suspensions of M2 Rif ${ }^{\mathrm{R}}$ at an $\mathrm{OD}_{600 \mathrm{~m}}$ of 0.01 were mixed with an equal volume of either genomic DNA extracted from 40288 (at $200 \mathrm{ng} / \mu \mathrm{L}$ ), a suspension of 40288 at an $\mathrm{OD}_{600 \mathrm{~mm}}$ of 0.01 of with or a filtered spent medium of a 4-hours culture in tryptone- $\mathrm{NaCl}$ medium of 40288 . The mixture $(2.5 \mu \mathrm{L})$ was deposited on the surface of tryptone- $\mathrm{NaCl}$ medium and incubated for 6 hours at $37^{\circ} \mathrm{C}$. Recombinant frequencies represent the ratio of Rif ${ }^{\mathrm{R}}$ and Imi ${ }^{\mathrm{R}}$ colonyforming units (CFUs) over the total. C. Contact-independent DNA release promotes both intra- and inter-strain recombination. The frequency of intra-strain recombinants from M2 Rif ${ }^{R}$ and M2 Apra ${ }^{R}$ strains was dermined in mixed culture or when M2 Rif ${ }^{R}$ is exposed to the spent medium of the M2 $\mathrm{Apra}^{\mathrm{R}}$ strain. To test for inter-strain recombination, M2 $\mathrm{Rif}^{\mathrm{R}}$ was mixed with $40288 \mathrm{Apra}^{\mathrm{R}}$ or with the spent medium from that strain. Recombinant frequencies represent the ratio of $\mathrm{Rif}^{\mathrm{R}}$ and Apra ${ }^{\mathrm{R}}$ colony-forming units (CFUs) over the total. D. Fluorescence-based quantification of DNA present in the spent medium of strains M2 and 40288. Samples treated with DNAse I represent the detection limit of such assay $(\sim 0.4 \mathrm{ng})$. When displayed $\mathrm{p}$-values of statistical analysis were obtained using the non-parametric Mann- Whitney-Wilcoxon test (two tailed). The limit of detection $\left(10^{-8}\right)$ is indicated by the grey area.

Given that DNA release is independent on the presence of another strain, DNA release and transformation may also occur between individuals of the same strain. We tested this possibility by looking at the ability of M2 RifR individuals to acquire the apramycin resistance marker $\left(\right.$ Apra $\left.^{R}\right)$ of a M2 $\triangle$ comEC mutant. In this mixed culture setup, Rif $/ A$ pra ${ }^{R}$ recombinants occurred at a frequency of $10^{-5}$ (Fig. 3C). The same frequency is observed when using spent medium of the M2 $\mathrm{Apra}^{\mathrm{R}} \triangle{ }^{\mathrm{C}} \mathrm{comEC}$ mutant to transform M2 Rif ${ }^{\mathrm{R}}$. Together, this shows that M2 cells spontaneously release DNA that can serve to transform other cells of the population. Yet, in a mixed culture setup, M2 acquired the apramycin resistance marker from $40288 \triangle$ comEC at higher rates than from itself (M2 $\triangle$ comEC) (Fig. $3 C$ ). The same result is observed with the spent medium, raising the possibility that the DNA released by 40288 is more potent to produce transformants. Given that M2 can be transformed at the same efficiency with the M2 or 40288 gDNA (Fig. S2), we hypothesized that 40288 simply releases more DNA than the M2 strain. Indeed, quantification of the DNA concentration in the spent medium from a 4-hours culture of both strains, showed that 40288 releases at least 3 times more DNA than the strain M2 (Fig. 3D). Yet, and surprisingly, quantities of DNA in spent media remain very low, with concentrations of around $2 \mathrm{ng} / \mu \mathrm{L}$ for the 40288 strain and $0.7 \mathrm{ng} / \mu \mathrm{L}$ for the M2 strain, which was almost as low as the detection limit $(0.4 \mathrm{ng} / \mathrm{\mu L}$, obtained with DNase I-treated samples). However, this low amount collected at 4 hours of growth is sufficient to generate transformants at frequencies comparable to those obtained with about 100 times larger amounts of purified gDNA in a 6-hours window (Fig. 3B). Overall, the data indicates that the amount of spontaneously released DNA is the major determinant of the rate of recombinants generated from individuals of the same or different strains. In conclusion, the T6SS-dependent and contact-independent release of small amount of genomic DNA by pathogenic Acinetobacter fuels horizontal gene transfer and the acquisition of antibiotic resistance genes.

\section{Acquisition of resistance can result from the horizontal transfer of large genomic islands}

To characterize the chromosomal transfer of the imipenem resistance at a genetic level, we sought to identify the imipenem resistance determinant in the 40288 donor strain and in transformants. 40288 is a carbapenem-resistant strain isolated from a diseased animal and carries the bla OXA-23 $_{3}$ carbapenem-resistance resistance gene (34). An initial assembly of the 40288 genome using Illumina reads resulted in 54 contigs,

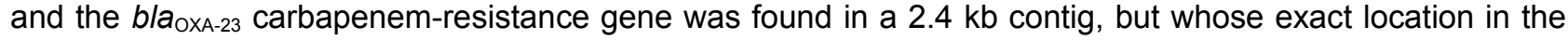
genome remained unresolved. A hybrid assembly combining the Illumina reads with long reads (Oxford Nanopore technology) resulted in the complete genome of 40288 showing a single circular contig of 4,084 $\mathrm{kb}$. The genome revealed the presence of the bla OxA-23 gene as part of the 4.8-kb Tn2006 transposon inserted at two distinct locations. One Tn2006 transposon is within the large AbaR4 island of 16-kb inserted in the comM gene, while the other copy is inserted in the beginning of the vgrG gene, encoding a T6SS component. This gene, in a putative operon with a LysM domain effector, is hereafter referred as vgrG3 (35). Insertion of the Tn2006 into vgrG3 gene did not impair T6SS-mediated killing, as introduction of this insertion in the vgrG3 gene of the M2 strain did not alter its T6SS-medated killing of E. coli and A. baumannii, contrarily to a $\Delta h c p$ mutant (Fig. S3).

Importantly, we found that either copy of bla the M2 strain (Table S3). However, the rate of their horizontal transfer may be affected by their genetic context. Acquisition of the blaoxA-23 gene from $v g r G 3:: T n 2006$ requires to incorporate $4.8 \mathrm{~kb}$ of heterologous sequence, while acquisition of the other copy would involve the acquisition of the whole AbaR4 island of 16.6 $\mathrm{kb}$. When genomic DNA from 40288 is provided to the M2 strain, the vast majority of imipenem-resistant transformants results from the acquisition of vgrG3::Tn2006, with only $5 \%$ of transformants acquiring the 16 kb-long AbaR4 island in comM (Fig. 4A). In contrast, under the mixed culture condition, this percentage increased 5-fold (Fig. 4A), suggesting that the mixed culture allows the acquisition of large DNA fragments. To further determine the length of imported DNA molecules under these conditions, we characterized by 
bioRxiv preprint doi: https://doi.org/10.1101/2021.08.05.455225; this version posted August 30, 2021. The copyright holder for this preprint (which was not certified by peer review) is the author/funder, who has granted bioRxiv a license to display the preprint in perpetuity. It is made available under aCC-BY-NC-ND 4.0 International license.

whole genome sequencing the extent of DNA recombination which had occurred in the M2 transformants. To this end, fifteen imipenem-resistant transformants of M2 obtained from mixed cultures with 40288 were analyzed: seven resulting from the acquisition of vgrG3::Tn2006 insertion and eight from the acquisition of comM::AbaR4. We used the nearly 300,000 SNPs between the two strains to identify the parts of the 40288 genome which had been incorporated in the M2 genome (Fig. S4A). The succession of acquired SNPs revealed discontinuous recombination tracts, on each sides of the acquired heterologous sequence (Fig. S4A). The discontinuous tracts most likely reflect multiple strand invasion events from the same imported DNA molecule (36). We thus used the position of the outermost acquired SNP to estimate the length of the DNA molecules of 40288 which was imported by the M2 recipients (Fig. 4B). We estimated that recombinants which have acquired Tn2006 in vgrG3 had imported DNA fragments ranging from 13 to $77 \mathrm{~kb}$ while those acquiring AbaR4 had imported DNA fragments ranging from 27 to $89 \mathrm{~kb}$ (Table S5). Thus, transformants resulted from the recombination of DNA molecules much larger that the acquired heterologous sequences. This suggests that the mixed culture is prone to allow the acquisition of large heterologous sequences such as those of genomic islands.

A

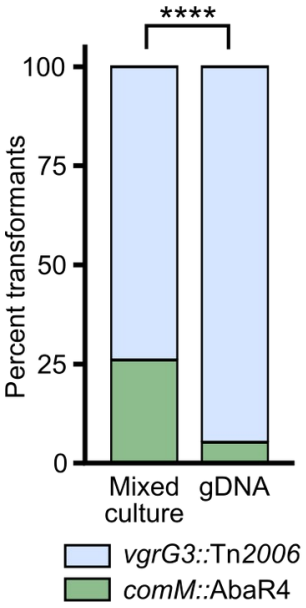

$\mathrm{B}$

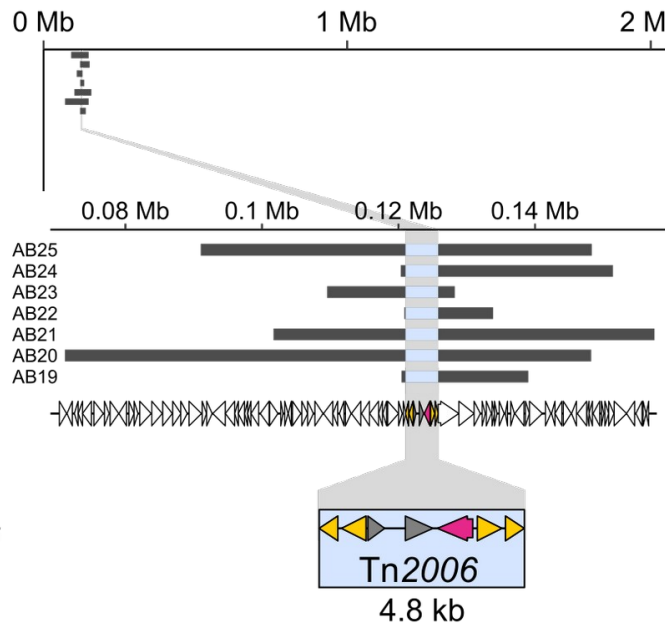

A. baumannii 40288 chromosome $3 \mathrm{Mb}$ $4 \mathrm{Mb}$
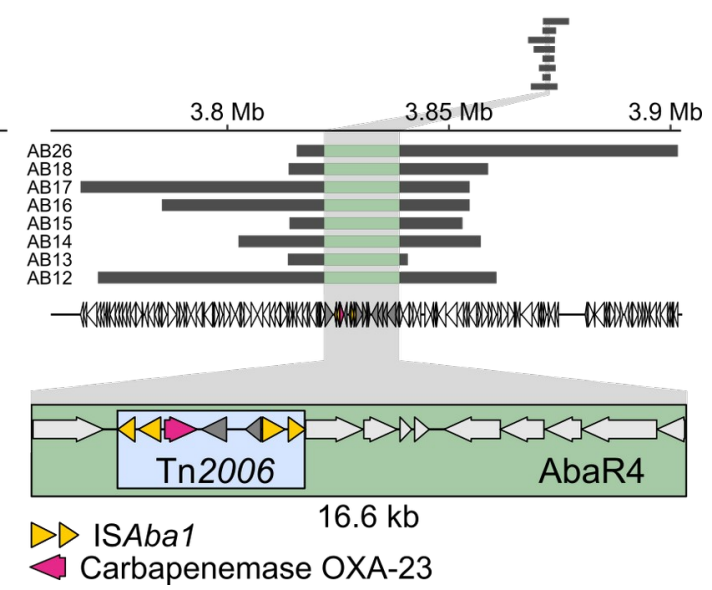

Figure 4. Genomic analysis of the acquisition of imipenem resistance.

A. PCR-based analysis of the chromosomal location of the Tn 2006 transposon and associated bla $_{O X A-23}$ gene conferring resistance to imipenem. One hundred $\mathrm{Imi}^{\mathrm{R}}$ and bla $_{O X A-23}$ PCR positive CFUs from 2 independent transformation assays were analyzed by PCR probing insertion in the comM gene. Statistical significance was calculated using Pearson's Chi-squared test returning p-value $<0.0001(* * * *)$. B. Graphical representation of the chromosome of the 40288 strain (thin black line) and location of the acquired DNA fragments (light grey thick lines) by transformants of the A. nosocomialis strain M2 during mixed culture with 40288 . Bottom left and right panels represent close-up of the regions in which the bla $a_{O X-23}$ gene is acquired as part of the Tn2006 element (blue box) in the $\operatorname{vgrG} 3$ gene and as part of the Tn2006 element within the AbaR island (green box) inserted in the comM gene. Acquired regions were determined by sequencing the genomes of imipenem-resistant recombinants of M2 which had acquired bla $a_{O X A-23}$ gene on a Novaseq instrument. Variant calling and identification of converted markers (SNPs of 40288 acquired by M2) were used to delineate the acquired regions (see Material and Methods).

The AbaR4 island is one of the many representatives of resistance islands that can be found in $A$. baumannii clinical isolates (9). The largest resistance island described so far, the $86 \mathrm{~kb}-$ long AbaR1, is found in the AYE strain (8). We thus tested whether this island could be acquired by the M2 strain. In a previous work, we showed that the AbaR1 island conferred resistance to aminoglycosides, tetracycline and to some betalactams (37). We thus used the tetracycline resistance as a marker for the transfer of AbaR1 from the $A$. baumannii strain AYE (donor strain) to the A. nosocomialis strain M2 (recipient strain). To test the acquisition of the AbaR1 by M2, we used the rifampicin resistant derivative of strain M2 and a derivative of the strain AYE impaired for natural transformation ( $\triangle$ comEC::aacC4). The mixed culture condition resulted in recombinants emerging at a frequency of about $10^{-7}$ (Fig. 5A). Noteworthy, only few transformants were detected when using purified genomic DNA, confirming that the mixed culture brings together conditions favorable to the transfer of large resistance island (Fig. 5A). The resulting transformants displayed the resistance profile expected from the known resistance associated with AbaR1 (Table S4), indicating that the entire $86 \mathrm{~kb}$-long island had indeed been acquired. Genome sequencing of three tetracycline resistant transformants confirmed that the entire AbaR1 island $(86 \mathrm{~kb})$ was inserted into the genome of the recipient 
bioRxiv preprint doi: https://doi.org/10.1101/2021.08.05.455225; this version posted August 30, 2021. The copyright holder for this preprint (which was not certified by peer review) is the author/funder, who has granted bioRxiv a license to display the preprint in perpetuity. It is made available under aCC-BY-NC-ND 4.0 International license.

cells (Fig. 5B and Fig. S4B). The recombination tracts flanking the comM locus indicated that the imported DNA molecules ranged from 112 to $123 \mathrm{~kb}$ (Fig. 5B and Fig. S4B). Taken together, these results demonstrate that recombinants can emerge from the encounter of Acinetobacter isolates, even if their genome display relatively low sequence identity $(90 \%)$. The interbacterial transfer can result in the efficient recombination of homologous regions and the acquisition of large heterologous segments up to $86 \mathrm{~kb}$, such as AbaR islands conferring resistance to multiple antibiotics, including to carbapenems.

A

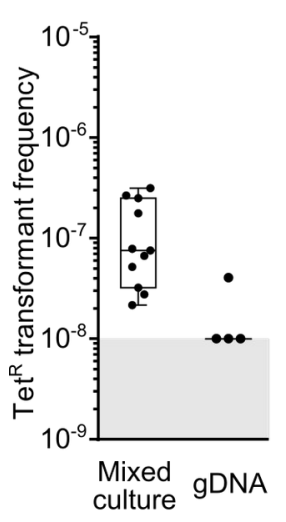

B

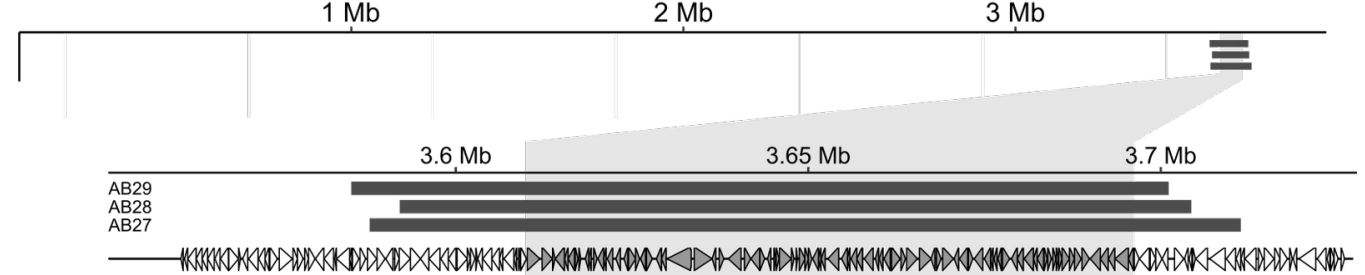

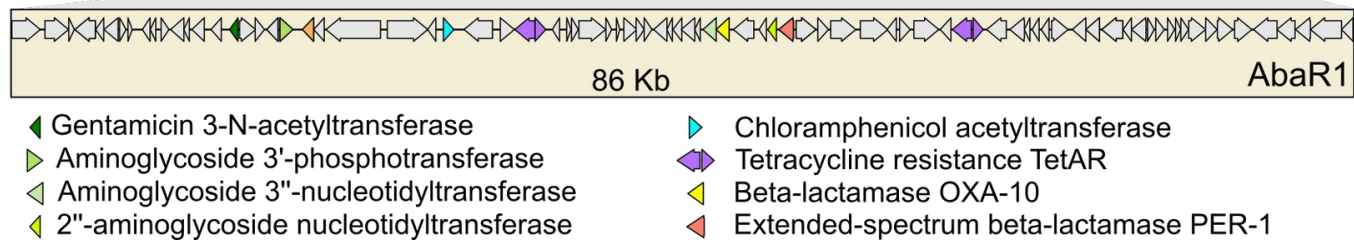

Figure 5. Genomic analysis of the acquisition of the AbaR1 island

A. Transformation frequencies of the acquisition of tetracycline resistance carried by the AbaR1 island of the AYE strain, in a mixed culture setup between the AYE strain impaired for natural transformation (comEC::aacC4) and the M2 Rif ${ }^{R}$ strain and by supplying M2 Rif ${ }^{\mathrm{R}}$ with genomic DNA extracted from AYE. B. Graphical representation of the chromosome of the AYE strain (thin black line) and location of the acquired DNA fragments (light grey thick lines) by transformants of the A. nosocomialis strain M2 during mixed culture with AYE. Bottom panel, close-up view of the acquired fragments and the AbaR1 island. The genomes of tetracycline-resistant recombinants of M2 were sequenced. Variant calling and identification of converted markers (SNPs of AYE acquired by M2) were used to delineate the acquired regions (see Material and Methods).

\section{Discussion}

To gain insight into the mechanism leading to emergence of carbapenem and more broadly multidrug resistance in pathogenic Acinetobacter sp. we devised an experimental system to monitor emergence of recombinant progeny and diffusion of antibiotic resistance between multiple combinations of pathogenic Acinetobacter strains. We observed that resistance is efficiently acquired within mixed populations of $A$. baumannii strains and even between $A$. baumannii and $A$. nosocomialis. With the panel of strains tested, we found an overall apparent correlation between the level of transformability of the isolates and the frequency of emergence of recombinant progeny. Investigating in more details a specific mixed population, we demonstrated that rapid gene transfer occurs through natural transformation in communities of sessile cells leading to antibiotic resistance. Resistance genes were either carried by composite transposon (Tn2006 carrying bla $\mathrm{OXA}_{-23}$ ) but also by large resistance island (AbaR4 and AbaR1). So far, demonstrations of gene acquisition by natural transformation in $A$. baumannii and $A$. nosocomialis were obtained using purified DNA (23-28). Our results indicate that this later form of DNA is a poor substrate for transformation in comparison to the DNA released in the extracellular milieu during growth or upon bacterial interaction. Mixed culture allowed a transfer of up to $123 \mathrm{~kb}$ from strain A. baumannii 40288 to A. nosocomialis corresponding to over $3 \%$ of the recipient strain's genome. Our results corroborate seminal observations in Streptococcus pneumoniae in which mixed sessile populations were found to support larger recombination events (up to 29 $\mathrm{kb}$ ) (38). Similarly, interaction of $V$. cholerae strains also promotes transfer of large genomic region (up to $168 \mathrm{~kb}$ ) (39). Importantly, our experiment recapitulate the observed recombination events associated with the acquisition of AbaGRI3 by a strain from the global clone 1 (GC1) originated from the GC2 (14). Acquisition by natural transformation would therefore explain the acquisition of AbaRs described in GC2 strains (40) but also in other Acinetobacter species from the $A$. baumannii-A. calcoaceticus complex, namely, $A$. nosocomialis, haemolyticus, pitii, and seifertii $(9,41,42)$. Our experimental observation leads to reconsider the role of natural transformation in the acquisition of large islands of resistance by $A$. baumannii previously attributed to generalized transduction based on presumed limited size of acquisition enabled by natural transformation (20). Transfer of very large resistance island such as AbaR1 are less frequent as the odds of importing an intact DNA are likely lower for long DNA fragments. Moreover, acquisition of new genetic 
bioRxiv preprint doi: https://doi.org/10.1101/2021.08.05.455225; this version posted August 30, 2021. The copyright holder for this preprint (which was not certified by peer review) is the author/funder, who has granted bioRxiv a license to display the preprint in perpetuity. It is made available under aCC-BY-NC-ND 4.0 International license.

material resistance genes has a potential cost on bacterial replication (43). In the specific case of AbaR1, importing numerous antibiotic and heavy metal resistance genes may be detrimental for the recipient strain with a temporary fitness cost that would affect the apparent transformation frequency $(44,45)$. If natural transformation is indeed a route of diffusion of large resistance island, these non-exclusive hypothesis would explain why resistance islands are mainly of about $20 \mathrm{~kb}$-long and carry a limited number of antibiotic resistance genes (9).

We investigated the role of T6SS in the transfer of resistance upon bacterial interaction. Indeed, this competition mechanism was an evident culprit to trigger the release of DNA from prey cells, as described for A. baylyi or $V$. cholerae $(31,32,39)$. Although we found that T6SS is partially involved in acquisition of resistance genes, we found however that T6SS mediated killing is potentially impaired in conditions compatible with natural transformation. Our results corroborate previous findings that T6SS development is dependent on growth conditions with the observation of a reduced T6SS activity determined by Hcp secretion in minimal medium for A. nosocomialis M2 strain (46). Contribution of T6SS in DNA release and diffusion of resistance determinants may however depend of strains combination, as T6SS activity was shown to be highly dependent of the strains in competitions $(35,47,48)$. In addition, our results show that the direct negative interaction between cells is not the sole mechanism promoting the release of DNA and the subsequent the acquisition of the resistance determinant. We found that the contact-independent release of DNA during growth is sufficient to mediate high rates of acquisition of resistance through natural transformation. Our results indicate that pathogenic Acinetobacter strains may release varying amount of DNA in the extracellular medium. In addition to passive release by autolysis upon cell death, several mechanisms of active DNA release in the extracellular compartment had been described in other transformable species. This release could be consecutive to a concerted lysis of a specific subpopulation. Indeed, competent cells of $S$. pneumoniae are able to recognize and kill non-competent kin cells leading to the lysis of up to $30 \%$ of the population $(49,50)$. In Neisseria gonorrhoeae, genomic DNA is actively secreted through a Type 4 Secretion System by the donor strain delivering a more potent substrate of transformation than DNA released upon autolysis $(51,52)$. In Pseudomonas aeruginosa, DNA release is dependent on a cryptic prophage endolysin that is required from biofilm formation where transformation can also occur (5355). We found that DNA concentration in the culture supernatant of $A$. baumannii strain 40288 was about 2 $\mathrm{ng} / \mathrm{\mu L}$ and a potent substrate for transformation, a result consistent with concentration measured in $P$. aeruginosa strain PAO1 culture (56). Extracellular DNA is also a critical component of biofilm matrix (57) and treatment with DNAse leads to severe biofilm alteration for several pathogenic bacteria, including $A$. baumannii (58). Inhibition of DNA release could therefore mitigate antibiotic resistance transmission by natural transformation and biofilm formation of this nosocomial pathogen. However, results obtained in $P$. aeruginosa demonstrates that biofilm-associated DNA is highly structured by nucleoproteins in a lattice that may partially impair its availability for transformation $(59,60)$. It is conceivable that level of DNA release may variate between strains of $A$. baumannii and thereby influence the diffusion of resistance gene and their acquisition by neighboring cells.

Altogether, this work highlights the importance of one of the major HGT mechanisms in bacteria, natural transformation, in the acquisition by $A$. baumannii of resistance to clinically relevant antibiotics. By naturally releasing high quality DNA in their environment, some strains of $A$. baumannii may be highly potent donors for the uptake and recombination of large DNA fragments by natural transformation. This mechanism may enable a rapid and direct acquisition of multiple antibiotic resistance genes by $A$. baumannii and explain the evolution by recombination observed at the genomic scale.

\section{Materials and Methods}

Bacterial strains and growth conditions. The bacterial strains or strains used in this study are listed in supplementary table S1. Unless specified, Acinetobacter baumannii isolates and strains were grown in lysogeny broth (LB) (Lennox). All experiments were performed at $37^{\circ} \mathrm{C}$. Antibiotic concentrations were: $15 \mu \mathrm{g} / \mathrm{mL}$ for tetracycline, $1.6 \mu \mathrm{g} / \mathrm{mL}$ for imipenem (always spread extemporaneously on LB agar plate) and $100 \mu \mathrm{g} / \mathrm{mL}$ for rifampicin.

Construction of bacterial strains. All the oligonucleotides used in this study for genetic modification are listed in supplementary table S2. Gene disruptions were performed using a scarless genome editing strategy described previously (37). Overlap extension PCR were used to synthesize large chimeric DNA fragments carrying the selection marker flanked by $2 \mathrm{~kb}$ fragments that are homologous to the insertion site. The oligonucleotides used for strain construction are listed in Table S2. The PCRs were performed with a high-fidelity DNA polymerase (PrimeStarMax, Takara).

Detection of recombinants in mixed cultures. Isolates to be tested for the production of recombinants were grown overnight on LB agar plates, then inoculated and grown in $2 \mathrm{~mL}$ of LB until the cultures reach an $\mathrm{OD}_{600 \mathrm{~nm}}$ of 1 . The bacterial broths were then diluted to an $\mathrm{OD}_{600 \mathrm{~nm}}$ of 0.01 in PBS. Then equal volumens of bacterial suspensions were mixed by pairs, each consisting of an imipenem-resistant $\left(\mathrm{Imi}^{\mathrm{R}}\right)$ and rifampicin-resistant $\left(\mathrm{Rif}^{\mathrm{R}}\right)$ isolate. The mixture $(2.5$ $\mu \mathrm{L}$ ) was deposited on the surface of $1 \mathrm{~mL}$ of tryptone- $\mathrm{NaCl}$ medium solidified with $2 \%$ agarose D3 (Euromedex) poured 
bioRxiv preprint doi: https://doi.org/10.1101/2021.08.05.455225; this version posted August 30, 2021. The copyright holder for this preprint (which was not certified by peer review) is the author/funder, who has granted bioRxiv a license to display the preprint in perpetuity. It is made available under aCC-BY-NC-ND 4.0 International license.

in $2 \mathrm{~mL}$ micro tubes or in wells of 24 -well plates and incubated overnight at $37^{\circ} \mathrm{C}$. Depending on the method used for plating, 200 or $400 \mu$ of DPBS, were added to the tubes which were vigorously vortexed to resuspend the bacteria. In 24 well plates, 200 or $400 \mu \mathrm{l}$ of DPBS and glass beads were added to the wells, the plates were then shaken to resuspend the bacteria. Suspension were plated on LB agar plates without antibiotics and LB agar plates containing rifampicin (100 $\mu \mathrm{g} / \mathrm{mL}$ ) and imipenem $(1.6 \mu \mathrm{g} / \mathrm{mL}$ ) either with beads or easySpiral Pro (Interscience). Recombinants frequencies were determined through calculation of the ratio of the number of CFUs on rifampicin and imipenem plates, to the total number of CFUs on plates without antibiotics.

Transformation assay. After overnight incubation at $37^{\circ} \mathrm{C}$ on $\mathrm{LB}$ agar, the strains were grown in $2 \mathrm{~mL}$ of $L B$ until $O D_{600 \mathrm{~nm}}$ of 1 . The bacterial broths were then diluted to an $\mathrm{OD}_{600 \mathrm{~nm}}$ of 0.01 in DPBS. Then bacterial suspensions of the recipient strain were mixed with an equal volume of either genomic DNA extracted from the donor strain (concentration 200 $\mathrm{ng} / \mu \mathrm{L}$ ), or a bacterial suspension of the donor strain at an $\mathrm{OD}_{600 \mathrm{~nm}}$ of 0.01 for mixed culture, or with a filtered spent medium of a 4-hours culture in tryptone- $\mathrm{NaCl}$ medium ( $5 \mathrm{~g} /$ liter of tryptone, $2.5 \mathrm{~g} /$ /iter $\mathrm{NaCl}$ ) of the donor strain. The mixture $(2.5 \mu \mathrm{L})$ was deposited on the surface of $1 \mathrm{~mL}$ of tryptone- $\mathrm{NaCl}$ medium solidified with $2 \%$ agarose $\mathrm{D} 3$ (Euromedex) poured in $2 \mathrm{~mL}$ micro tubes and incubated overnight at $37^{\circ} \mathrm{C}$. The next day, bacteria were recovered by resuspension in $300 \mu \mathrm{L}$ of PBS, serial diluted and spread on LB agar plate without antibiotic or supplemented with the appropriate antibiotic. In experiments including DNAse I treatment, 0.6U of DNAse I (Sigma) were added per microliter of the mixed culture. All the transformation assays were performed on at least two separate occasions. On each occasion, three independent transformation reactions were conducted (three different bacterial cultures). All the independent data points are plotted. As normality of the distribution of transformation frequency does not apply for transformation frequency analysis, non-parametric tests were performed (Mann-Whitney-Wilcoxon).

For kinetics of transformation, bacteria were recovered from the solidified tryptone- $\mathrm{NaCl}$ medium at various times points: 0 and 30 min after contact, then one point every hour from 1 to 8 hours after contact and one final point at 24 hours after contact. For each point, bacteria were harvested from an independent sample and plated as previously described.

Determination of antagonistic activity between strains. T6SS-dependent killing activity of the M2 strain were determined in LB medium and in conditions of mixed culture, as previously described (33). Strains were grown $2 \mathrm{~h}$ at $37^{\circ} \mathrm{C}$ in the indicated liquid medium, then were diluted to an $\mathrm{OD}_{600 \mathrm{~nm}}$ of 0.4 . The bacterial suspensions were then mixed at a ratio of $10: 1$ (predator:prey) and $10 \mu \mathrm{L}$ of the mixed suspension were spotted on a dried plate and incubated at $37^{\circ} \mathrm{C}$ during $4 \mathrm{~h}$. Bacteria were then collected from the plate, resuspended and serial dilution were plated on selective plate to determine the titer of prey bacteria. Plates containing kanamycin and imipenem were used to selectively recover the prey bacteria E. coli JW2912 and A. baumannii 40288, respectively.

DNA measurement in spent media. Bacteria were prepared as for transformation assay lasting $4 \mathrm{~h}$ at $37^{\circ} \mathrm{C}$ in $2 \mathrm{~mL}-$ eppendorf tubes. After the $4 \mathrm{~h}$ incubation, the cells were harvested with $300 \mu \mathrm{L}$ of sterile water. As control, $25 \mu \mathrm{L}$ of the bacterial suspension were used for serial dilutions in 96-well plates for numbering on LB agar with or without supplements to verify the survival and M2 transformation efficiencies. DNA quantification in the spent medium of the donor was performed through fluorescent labelling with Quant-iT reagent (Invitrogen Qubit dsDNA HS Assay Kit, Thermo Fisher Scientific). Fluorescence was measured with Infinite M200 PRO (TECAN) and Magellan 7.1 SP1 (TECAN) and DNA concentration was calculated by comparison with Quant-iT standards (Invitrogen Qubit dsDNA HS Assay Kit, Thermo Fisher Scientific) in liquid Tryptone $\mathrm{NaCl}$ medium.

Genome sequencing, assembly, and annotations. The genome of 40288 was sequenced using the Illumina technology (paired-end 100, HiSeq instrument) and Oxford nanopore technology (rapid barcoding kit, Minlon instrument) with a read coverage of $100 \mathrm{X}$. Short (Illumina) and long (Oxford nanopore) reads were used to assemble the genome with Unicycler (61). This generated a complete genome consisting of a circular chromosome of 4,084,922 bp and circular plasmid of $145,711 \mathrm{bp}$. Genes were annotated with Prokka (62), using the A. baumannii AB5075-UW genome as reference (63). The genome of the human clinical isolate CNRAB1 was sequenced using similar procedures. Genome sequences are available within the bioproject PRJNA741866.

Variant-calling and detection of recombination events.

The genomes of imipenem-resistant recombinants of M2 which had acquired bla oxA-23 were sequenced on a Novaseq instrument (Illumina, $2 \times 150 \mathrm{bp}$ paired-end, $300 \mathrm{bp}$ insertion length). Sequencing reads were subsampled to match an estimated 50x coverage of donor genome using seqtk version 1.3-r106 (https://github.com/lh3/seqtk). Reads of recombinants were mapped to their corresponding donor genome (M2, 40288 or AYE) using bwa mem version 0.7.17r1888 (64) and sorted using samtools version 1.10.3 (65). Donor (40288 or AYE) and recipient (M2) genome short reads were simulated using wgsim version 1.10 (https://github.com/lh3/wgsim) and mapped to the donor genome (40288 or AYE) using the same parameters as for transformant sequencing reads. Reads were then tallied on donor genome using bcftools version 1.10 , to keep only sites with read coverage above $25 x$, where haplotype differs between donor and recipient, and match donor haplotype. These variant calling and identification of converted markers were performed using twgt version 0.1.0.5 (https://gitlab.com/bacterial-gbgc/twgt/-/tree/master) The resulting VCF file was then parsed using VariantAnnotation (66) from the Bioconductor framework version 3.10, using $\mathrm{R}$ version 3.6.6. Tn2006, AbaR4 and AbaR 1 being absent from recipient genome, they cannot be detected from single nucleotide polymorphisms and short insertions/deletions. Their insertions in the transformant genome was thus confirmed via read screening: their sequence together with $1 \mathrm{~kb}$ of flanking sequence was sketched using mash sketch with default parameters; the presence of this sketches in sequencing reads was confirmed using mash screen version 2.2 .2 (67). Recombinants carrying AbaR4 correspond to samples AB12 to AB18 and AB26. Recombinants carrying Tn2006 in vgrG correspond to samples AB19 to AB25. Recombinants carrying AbaR1 are samples AB27 to 29. Raw sequencing reads are available as Sequence Read Archive (SRA) within PRJNA741866. 
bioRxiv preprint doi: https://doi.org/10.1101/2021.08.05.455225; this version posted August 30, 2021. The copyright holder for this preprint (which was not certified by peer review) is the author/funder, who has granted bioRxiv a license to display the preprint in perpetuity. It is made available under aCC-BY-NC-ND 4.0 International license.

\section{Acknowledgments}

We warmly thank Agnese Lupo and Marisa Haenni (Unité Antibiorésistance et Virulence Bactériennes, ANSES, Lyon, France) for sharing the clinical isolate 40288, sequencing data and antimicrobial susceptibility testing data. This work was supported by the LABEX ECOFECT (ANR-11-LABX-0048) of Universite de Lyon, within the program "Investissements d'Avenir" (ANR-11-IDEX-0007) operated by the French National Research Agency (ANR). ASG and MHL were also supported by Programme Jeune Chercheur from VetAgro Sup. AL and MHL were supported by the French Agency for Food, Environmental and Occupational Health \& Safety (ANSES).

\section{References}

1. Dijkshoorn L, Nemec A, Seifert H. 2007. An increasing threat in hospitals: multidrug-resistant Acinetobacter baumannii. Nat Rev Microbiol 5:939-951.

2. van der Kolk JH, Endimiani A, Graubner C, Gerber V, Perreten V. 2019. Acinetobacter in veterinary medicine, with an emphasis on Acinetobacter baumannii. J Glob Antimicrob Resist 16:59-71.

3. Patel A, Emerick M, Cabunoc MK, Williams MH, Preas MA, Schrank G, Rabinowitz R, Luethy P, Johnson JK, Leekha S. 2021. Rapid Spread and Control of Multidrug-Resistant Gram-Negative Bacteria in COVID-19 Patient Care Units. Emerg Infect Dis 27:1234-1237.

4. Perez S. 2020. Increase in Hospital-Acquired Carbapenem-Resistant Acinetobacter baumannii Infection and Colonization in an Acute Care Hospital During a Surge in COVID-19 Admissions — New Jersey, February-July 2020. MMWR Morb Mortal Wkly Rep 69.

5. European Centre for Disease Prevention and Control. 2020. Antimicrobial resistance in the EU/EEA (EARS-Net) -Annual Epidemiological Report 2019. ECDC, Stockholm.

6. Hamidian M, Nigro SJ. 2019. Emergence, molecular mechanisms and global spread of carbapenem-resistant Acinetobacter baumannii. Microbial Genomics, $5: \mathrm{e} 000306$.

7. Nigro S, Hall RM. 2015. Distribution of the blaOXA-23-containing transposons Tn2006 and Tn2008 in Australian carbapenemresistant Acinetobacter baumannii isolates. J Antimicrob Chemother 70:2409-2411.

8. Fournier P-E, Vallenet D, Barbe V, Audic S, Ogata H, Poirel L, Richet H, Robert C, Mangenot S, Abergel C, Nordmann P, Weissenbach J, Raoult D, Claverie J-M. 2006. Comparative genomics of multidrug resistance in Acinetobacter baumannii. PLoS Genet 2:e7.

9. Bi D, Xie R, Zheng J, Yang H, Zhu X, Ou H-Y, Wei Q. 2019. Large-Scale Identification of AbaR-Type Genomic Islands in Acinetobacter baumannii Reveals Diverse Insertion Sites and Clonal Lineage-Specific Antimicrobial Resistance Gene Profiles. Antimicrob Agents Chemother 63.

10. Bonnin RA, Poirel L, Nordmann P. 2012. AbaR-type transposon structures in Acinetobacter baumannii. J Antimicrob Chemother 67:234-236.

11. Hamidian M, Hall RM. 2018. The AbaR antibiotic resistance islands found in Acinetobacter baumannii global clone 1 Structure, origin and evolution. Drug Resist Updat 41:26-39.

12. Hamidian M, Hall RM. 2017. Origin of the AbGRI1 antibiotic resistance island found in the comM gene of Acinetobacter baumannii GC2 isolates. 10. J Antimicrob Chemother 72:2944-2947.

13. Hamidian M, Kenyon JJ, Holt KE, Pickard D, Hall RM. 2014. A conjugative plasmid carrying the carbapenem resistance gene blaOXA-23 in AbaR4 in an extensively resistant GC1 Acinetobacter baumannii isolate. 10. J Antimicrob Chemother 69:26252628.

14. Hamidian M, Hawkey J, Wick R, Holt KE, Hall RM. 2019. Evolution of a clade of Acinetobacter baumannii global clone 1, lineage 1 via acquisition of carbapenem- and aminoglycoside-resistance genes and dispersion of ISAba1. Microb Genom 5.

15. Hua X, Moran RA, Xu Q, He J, Fang Y, Zhang L, van Schaik W, Yu Y. 2021. Acquisition of a genomic resistance island (AbGRI5) from global clone 2 through homologous recombination in a clinical Acinetobacter baumannii isolate. 1. Journal of Antimicrobial Chemotherapy 76:65-69.

16. Snitkin ES, Zelazny AM, Montero CI, Stock F, Mijares L, NISC Comparative Sequence Program, Murray PR, Segre JA. 2011. Genome-wide recombination drives diversification of epidemic strains of Acinetobacter baumannii. Proceedings of the National Academy of Sciences 108:13758-13763.

17. Holt K, Kenyon JJ, Hamidian M, Schultz MB, Pickard DJ, Dougan G, Hall R. 2016. Five decades of genome evolution in the globally distributed, extensively antibiotic-resistant Acinetobacter baumannii global clone 1. Microbial Genomics 2.

18. Douraghi M, Kenyon JJ, Aris P, Asadian M, Ghourchian S, Hamidian M. 2020. Accumulation of Antibiotic Resistance Genes in Carbapenem-Resistant Acinetobacter baumannii Isolates Belonging to Lineage 2, Global Clone 1, from Outbreaks in 2012 2013 at a Tehran Burns Hospital. 2. mSphere 5.

19. Wright MS, Iovleva A, Jacobs MR, Bonomo RA, Adams MD. 2016. Genome dynamics of multidrug-resistant Acinetobacter baumannii during infection and treatment. 1. Genome Medicine 8.

20. Krahn T, Wibberg D, Maus I, Winkler A, Bontron S, Sczyrba A, Nordmann P, Pühler A, Poirel L, Schlüter A. 2016. Intraspecies Transfer of the Chromosomal Acinetobacter baumannii bla $\mathrm{NDM}_{-1}$ Carbapenemase Gene. 5. Antimicrob Agents Chemother 60:3032-3040.

21. Wachino J-I, Jin W, Kimura K, Arakawa Y. 2019. Intercellular Transfer of Chromosomal Antimicrobial Resistance Genes between Acinetobacter baumannii Strains Mediated by Prophages. 8. Antimicrob Agents Chemother 63:e00334-19.

22. Johnston C, Martin B, Fichant G, Polard P, Claverys J-P. 2014. Bacterial transformation: distribution, shared mechanisms and divergent control. Nat Rev Microbiol 12:181-196. 
bioRxiv preprint doi: https://doi.org/10.1101/2021.08.05.455225; this version posted August 30, 2021. The copyright holder for this preprint (which was not certified by peer review) is the author/funder, who has granted bioRxiv a license to display the preprint in perpetuity. It is made available under aCC-BY-NC-ND 4.0 International license.

23. Godeux A-S, Lupo A, Haenni M, Guette-Marquet S, Wilharm G, Laaberki M-H, Charpentier X. 2018. Fluorescence-Based Detection of Natural Transformation in Drug-Resistant Acinetobacter baumannii. Journal of Bacteriology 200:e00181-18.

24. Harding CM, Tracy EN, Carruthers MD, Rather PN, Actis LA, Munson RS. 2013. Acinetobacter baumannii Strain M2 Produces Type IV Pili Which Play a Role in Natural Transformation and Twitching Motility but Not Surface-Associated Motility. mBio 4.

25. Traglia GM, Chua K, Centrón D, Tolmasky ME, Ramírez MS. 2014. Whole-genome sequence analysis of the naturally competent Acinetobacter baumannii clinical isolate A118. 9. Genome biology and evolution 6:2235-2239.

26. Wilharm G, Piesker J, Laue M, Skiebe E. 2013. DNA uptake by the nosocomial pathogen Acinetobacter baumannii occurs during movement along wet surfaces. J Bacteriol 195:4146-4153.

27. Vesel N, Blokesch M. 2021. Pilus Production in Acinetobacter baumannii Is Growth Phase Dependent and Essential for Natural Transformation. Journal of Bacteriology 203.

28. $\mathrm{Hu}$ Y, He L, Tao X, Meng F, Zhang J. 2019. High DNA Uptake Capacity of International Clone II Acinetobacter baumannii Detected by a Novel Planktonic Natural Transformation Assay. Front Microbiol 10:2165.

29. Hall AR, Iles JC, MacLean RC. 2011. The Fitness Cost of Rifampicin Resistance in Pseudomonas aeruginosa Depends on Demand for RNA Polymerase. Genetics 187:817-822.

30. Brandis G, Pietsch F, Alemayehu R, Hughes D. 2015. Comprehensive phenotypic characterization of rifampicin resistance mutations in Salmonella provides insight into the evolution of resistance in Mycobacterium tuberculosis. Journal of Antimicrobial Chemotherapy 70:680-685.

31. Borgeaud S, Metzger LC, Scrignari T, Blokesch M. 2015. The type VI secretion system of Vibrio cholerae fosters horizontal gene transfer. Science 347:63-67.

32. Ringel PD, Hu D, Basler M. 2017. The Role of Type VI Secretion System Effectors in Target Cell Lysis and Subsequent Horizontal Gene Transfer. Cell Reports 21:3927-3940.

33. Carruthers MD, Nicholson PA, Tracy EN, Jr RSM. 2013. Acinetobacter baumannii Utilizes a Type VI Secretion System for Bacterial Competition. 3. PLOS ONE 8:e59388.

34. Lupo A, Châtre P, Ponsin C, Saras E, Boulouis H-J, Keck N, Haenni M, Madec J-Y. 2016. Clonal Spread of Acinetobacter baumannii Sequence Type 25 Carrying blaOXA-23 in Companion Animals in France. Antimicrob Agents Chemother 61.

35. Fitzsimons TC, Lewis JM, Wright A, Kleifeld O, Schittenhelm RB, Powell D, Harper M, Boyce JD. 2018. Identification of Novel Acinetobacter baumannii Type VI Secretion System Antibacterial Effector and Immunity Pairs. Infect Immun 86:e0029718.

36. Alfsnes K, Frye SA, Eriksson J, Eldholm V, Brynildsrud OB, Bohlin J, Harrison OB, Hood DW, Maiden MCJ, Tønjum T, Ambur OH. 2018. A genomic view of experimental intraspecies and interspecies transformation of a rifampicin-resistance allele into Neisseria meningitidis. Microb Genom 4.

37. Godeux A-S, Svedholm E, Lupo A, Haenni M, Venner S, Laaberki M-H, Charpentier X. 2020. Scarless Removal of Large Resistance Island AbaR Results in Antibiotic Susceptibility and Increased Natural Transformability in Acinetobacter baumannii. Antimicrob Agents Chemother 64.

38. Cowley LA, Petersen FC, Junges R, Jimenez MJD, Morrison DA, Hanage WP. 2018. Evolution via recombination: Cell-to-cell contact facilitates larger recombination events in Streptococcus pneumoniae. PLOS Genetics 14:e1007410.

39. Matthey N, Stutzmann S, Stoudmann C, Guex N, Iseli C, Blokesch M. 2019. Neighbor predation linked to natural competence fosters the transfer of large genomic regions in Vibrio cholerae. eLife 8:e48212.

40. Iacono M, Villa L, Fortini D, Bordoni R, Imperi F, Bonnal RJP, Sicheritz-Ponten T, De Bellis G, Visca P, Cassone A, Carattoli A. 2008. Whole-genome pyrosequencing of an epidemic multidrug-resistant Acinetobacter baumannii strain belonging to the European clone II group. Antimicrob Agents Chemother 52:2616-2625.

41. Kim DH, Choi J-Y, Kim HW, Kim SH, Chung DR, Peck KR, Thamlikitkul V, So TM-K, Yasin RMD, Hsueh P-R, Carlos CC, Hsu LY, Buntaran L, Lalitha MK, Song J-H, Ko KS. 2013. Spread of Carbapenem-Resistant Acinetobacter baumannii Global Clone 2 in Asia and AbaR-Type Resistance Islands. Antimicrob Agents Chemother 57:5239-5246.

42. Kim DH, Ko KS. 2015. AbaR-type genomic islands in non-baumannii Acinetobacter species isolates from South Korea. Antimicrob Agents Chemother 59:5824-5826.

43. Baltrus DA. 2013. Exploring the costs of horizontal gene transfer. Trends Ecol Evol (Amst) 28:489-495.

44. Gullberg E, Albrecht LM, Karlsson C, Sandegren L, Andersson DI. 2014. Selection of a Multidrug Resistance Plasmid by Sublethal Levels of Antibiotics and Heavy Metals. mBio 5:e01918-14.

45. Vogwill T, MacLean RC. 2015. The genetic basis of the fitness costs of antimicrobial resistance: a meta-analysis approach. Evol Appl 8:284-295.

46. Harding CM, Pulido MR, Venanzio GD, Kinsella RL, Webb AI, Scott NE, Pachón J, Feldman MF. 2017. Pathogenic Acinetobacter species have a functional type I secretion system and contact-dependent inhibition systems. 22. J Biol Chem 292:9075-9087.

47. Repizo GD, Gagné S, Foucault-Grunenwald M-L, Borges V, Charpentier X, Limansky AS, Gomes JP, Viale AM, Salcedo SP. 2015. Differential Role of the T6SS in Acinetobacter baumannii Virulence. PLoS ONE 10:e0138265.

48. Weber BS, Miyata ST, Iwashkiw JA, Mortensen BL, Skaar EP, Pukatzki S, Feldman MF. 2013. Genomic and Functional Analysis of the Type VI Secretion System in Acinetobacter. 1. PLoS One 8.

49. Guiral S, Mitchell TJ, Martin B, Claverys J-P. 2005. Competence-programmed predation of noncompetent cells in the human pathogen Streptococcus pneumoniae: Genetic requirements. 24. Proc Natl Acad Sci U S A 102:8710-8715.

50. Eldholm V, Johnsborg O, Haugen K, Ohnstad HS, Håvarstein LS. 2009. Fratricide in Streptococcus pneumoniae: contributions and role of the cell wall hydrolases CbpD, LytA and LytC. 7. Microbiology 155:2223-2234.

51. Dillard JP, Seifert HS. 2001. A variable genetic island specific for Neisseria gonorrhoeae is involved in providing DNA for natural transformation and is found more often in disseminated infection isolates. 1. Molecular Microbiology 41:263-277.

52. Hamilton HL, Domínguez NM, Schwartz KJ, Hackett KT, Dillard JP. 2005. Neisseria gonorrhoeae secretes chromosomal DNA via a novel type IV secretion system. 6. Molecular Microbiology 55:1704-1721. 
bioRxiv preprint doi: https://doi.org/10.1101/2021.08.05.455225; this version posted August 30, 2021. The copyright holder for this preprint (which was not certified by peer review) is the author/funder, who has granted bioRxiv a license to display the preprint in perpetuity. It is made available under aCC-BY-NC-ND 4.0 International license.

53. Turnbull L, Toyofuku M, Hynen AL, Kurosawa M, Pessi G, Petty NK, Osvath SR, Cárcamo-Oyarce G, Gloag ES, Shimoni R, Omasits U, Ito S, Yap X, Monahan LG, Cavaliere R, Ahrens CH, Charles IG, Nomura N, Eberl L, Whitchurch CB. 2016. Explosive cell lysis as a mechanism for the biogenesis of bacterial membrane vesicles and biofilms. Nat Commun 7.

54. Hynen AL, Lazenby JJ, Savva GM, McCaughey LC, Turnbull L, Nolan LM, Whitchurch CB. 2021. Multiple holins contribute to extracellular DNA release in Pseudomonas aeruginosa biofilms. 2. Microbiology (Reading) 167.

55. Nolan LM, Turnbull L, Katrib M, Osvath SR, Losa D, Lazenby JJ, Whitchurch CBY 2020. 2020. Pseudomonas aeruginosa is capable of natural transformation in biofilms. 10. Microbiology 166:995-1003.

56. Allesen-Holm M, Barken KB, Yang L, Klausen M, Webb JS, Kjelleberg S, Molin S, Givskov M, Tolker-Nielsen T. 2006. A characterization of DNA release in Pseudomonas aeruginosa cultures and biofilms. 4. Molecular Microbiology 59:1114-1128.

57. Okshevsky M, Meyer RL. 2015. The role of extracellular DNA in the establishment, maintenance and perpetuation of bacterial biofilms. 3. Critical Reviews in Microbiology 41:341-352.

58. Tetz GV, Artemenko NK, Tetz VV. 2009. Effect of DNase and Antibiotics on Biofilm Characteristics. Antimicrobial Agents and Chemotherapy 53:1204-1209.

59. Devaraj A, Buzzo JR, Mashburn-Warren L, Gloag ES, Novotny LA, Stoodley P, Bakaletz LO, Goodman SD. 2019. The extracellular DNA lattice of bacterial biofilms is structurally related to Holliday junction recombination intermediates. 50 PNAS 116:25068-25077.

60. Jurcisek JA, Brockman KL, Novotny LA, Goodman SD, Bakaletz LO. 2017. Nontypeable Haemophilus influenzae releases DNA and DNABII proteins via a T4SS-like complex and ComE of the type IV pilus machinery. 32. Proc Natl Acad Sci U S A 114:E6632-E6641.

61. Wick RR, Judd LM, Gorrie CL, Holt KE. 2017. Unicycler: Resolving bacterial genome assemblies from short and long sequencing reads. PLoS Comput Biol 13:e1005595.

62. Seemann T. 2014. Prokka: rapid prokaryotic genome annotation. Bioinformatics 30:2068-2069.

63. Jacobs AC, Thompson MG, Black CC, Kessler JL, Clark LP, McQueary CN, Gancz HY, Corey BW, Moon JK, Si Y, Owen MT, Hallock JD, Kwak YI, Summers A, Li CZ, Rasko DA, Penwell WF, Honnold CL, Wise MC, Waterman PE, Lesho EP, Stewart RL, Actis LA, Palys TJ, Craft DW, Zurawski DV. 2014. AB5075, a Highly Virulent Isolate of Acinetobacter baumannii, as a Model Strain for the Evaluation of Pathogenesis and Antimicrobial Treatments. MBio 5:e01076-01014.

64. Li H, Durbin R. 2009. Fast and accurate short read alignment with Burrows-Wheeler transform. Bioinformatics 25:1754-1760.

65. Li H. 2011. A statistical framework for SNP calling, mutation discovery, association mapping and population genetical parameter estimation from sequencing data. Bioinformatics 27:2987-2993.

66. Obenchain V, Lawrence M, Carey V, Gogarten S, Shannon P, Morgan M. 2014. VariantAnnotation : a Bioconductor package for exploration and annotation of genetic variants. Bioinformatics 30:2076-2078.

67. Ondov BD, Treangen TJ, Melsted P, Mallonee AB, Bergman NH, Koren S, Phillippy AM. 2016. Mash: fast genome and metagenome distance estimation using MinHash. Genome Biology 17:132. 